Volume 4 Number 4 June 2021

\title{
Innovation Strategy on Online-Based Library Services to Achieve Freedom Learning Program during Covid 19
}

\author{
M. Afif Hasbullah, Nisaul Barokati Seliro Wangi \\ Universitas Islam Darul Ulum Lamongan \\ afif@unisda.ac.id,nisa@unisda.ac.id
}

\begin{tabular}{ll}
\hline Article History & Received : January 9 $9^{\text {th }} 2021$ \\
& Revision : Marchy 13th 2021 \\
& Publication : June 30 3021 \\
\hline
\end{tabular}

\begin{abstract}
The Covid-19 pandemic has had a significant impact on the implementation of teaching and learning activities, especially libraries as critical factor in maintaining good education. The Covid-19 outbreak has impacted the availability of instructional resources, reading materials, literacy, and other information. To ensure successful implementation, libraries must constantly innovate services through the use of information technology advances, including developing e-digital library services, online libraries, and book delivery services, as well as developing big data and digital library applications that involve libraries throughout Indonesia. Even the world through the use of a system that is frequently found in digital e-commerce platforms.
\end{abstract}

Keywords: Innovation, library services, digital library, online library.

\section{INTRODUCTION}

For the previous two years, the world has been devastated by the COVID-19 pandemic. For the last year and a half, the COVID-19 pandemic has been endemic in Indonesia. This has had extraordinary social and economic consequences, including pushing people to adopt a new culture in terms of how they work, study, and participate in activities. Numerous new habits emerge as a result of the need to adapt to changing conditions.

Education is one of the most severely impacted public sectors by the COVID-19 pandemic. Hundreds of countries have closed their schools. The school activities can be conducted from home using electronic network devices, such as the internet. Online education platforms are quickly increasing in response to the increased demand for educational services.

Zoom conference, Google Class Room, and other digital meeting technologies that existed previously but were unused became the primary service required by many 
people during the Covid-19 pandemic. Application development for delivery services that address community needs is also increasing. Previously, food delivery services such as go-food, grab-food, and others existed. However, during a pandemic with restrictions on public mobility, food delivery services are growing rapidly to meet people's daily consumption needs.

Libraries play an important role in achieving educational goals. If an educational institution's building is closed, the library is usually closed. Even if t educational area and face-to-face learning are restricted in this pandemic, it should not hinder the continued functioning of educational institutions to educate the community.

Finally, learning must be implemented online or via online media. Educators, including teachers, lecturers, and instructors, can communicate with students, students among other students through online learning media, such as laptops, computer PCs, and mobile phones.

As the primary support system for educational activities, many libraries have barely increased in terms of service innovation, such as online learning. As a result, library services are no longer available to the public in the extent in which they were before the Covid-19 pandemic. Whereas students and teachers require library services.

The shift from work from office to work from home, and learning from school to learning from home makes the library be accessible from the homes of each student or user of library. However, how is the readiness of the library in a pandemic condition? These questions become challenge that needs to be answered and realized immediately. This also needs to consider the library's current condition, which is mostly unprepared for the total online service environment.

No one in the health sector knows when the Covid-19 pandemic will end. Thus, a strategy is required to ensure that all human activities continue to run smoothly.

The strategy is important in overcoming numerous essential activities of the company/institution/institution/organization in uncertain and difficult to anticipate future situations. By implementing a strategy, a company/institution/institution/organization is trying to maximize potential while developing adaptability to a fast changing environment. Strategy as a formal step is not enough. Strategy as a formal step is not enough, it must be with a substance called innovation. Innovation is intended as a conceptualization activity, as well as an idea to solve problems by bringing economic value to companies/institutions/institutions/organizations and social values to society. So when you innovate from something already existing, you add value. To innovate, one must first open their eyes and ears to the ambitions or complaints of consumers, employees, the environment, and society. 
Several previous scientific studies discussed library service advances during the pandemic of covid-19. However, it is generally limited to the services that each library can offer its internal customers, or to each school/campus.

In addition to assisting the Government's independent learning program, the momentum of the Covid-19 epidemic is the ideal time to integrate online services from various libraries into a library service application. It is expected that library services can be provided more efficiently, both in terms of the number of libraries accessible and the number of reading sources accessible.

\section{METHOD}

The research method was a scientific approach used to collect data for a certain objective. The scientific term in the Big Indonesian Dictionary (KBBI) had a scientific meaning or complied with scientific requirements (rules) for accounting for the truth.

The writer used descriptive research methods because the purpose of this study was to elicit responses, opinions, or perceptions, and thus the discussion must be qualitative or based on word descriptions. "Descriptive research aims to develop a comprehensive and accurate account of all activities, objects, processes, and people."

Descriptive research operates on a number of different forms, including surveys, case studies, investigations, causal-comparative, and correlation studies. Each type of descriptive research has a different function and goal, and this type of descriptive research is classified as a "case study."

A "case study" is an in-depth study of specific events, locations, and situations that enables the disclosure or comprehension of anything. The writer used the "case study" method of research to highlight the phenomena that exists in the library in the educational environment regarding the number of libraries that are unable to provide offline services as a result of the Covid-19 pandemic's impact and the solutions. The writer merely analyzes few sample of the library in a few locations; it is expected that that the conclusions drawn can be applied in general.

\section{RESULTS AND DISCUSSION}

Many countries have enacted a variety of regulations aimed at controlling the spread of COVID-19. The Indonesian government has taken preventive steps to lessen the impact and spread of COVID-19 by implementing physical distancing regulations (requiring a minimum physical distance of two meters), which are strengthened by the large periodic social restriction (PSBB) policy regulated in Government Regulation No. 21 of 2020. These restrictions are to reduce large crowds of individuals involved in activities that have the potential to increase COVID-19 transmission, such as 
educational/learning activities, religious activities, work activities, public activities, and social activities.

According to Kompas.com, Wiku Adisasmita, the Head of the Expert Team for the Task Force for the Acceleration of COVID-19 Handling, stated that the new normal is shifting activities in how normal activities are carried out, but with health protocols to prevent COVID-19 transmission, such as avoiding physical contact with other people and avoiding crowds, as well as work and school away from home. This shift is necessary because a vaccination for this virus has not yet been discovered, but daily operations must continue.

According to Tirto.id, the Indonesian government's concept of new-normal is a new order to adapt new activities during pandemic of COVID-19. Adapting to COVID-19 can be accomplished by practicing a clean and healthy lifestyle in daily activities such as meticulously washing hands with soap, wearing masks while leaving the house, keeping a safe distance from other people, avoiding crowding, and maintaining immunity as well as others.

\section{A New Normal Era in Library Service}

The global pandemic that currently occurred as a result of the spread of the COVID-19 virus has an impact on libraries as one of the accesses to public services. The government's recommendation to restrict activities outside the home has led in the closing of numerous physical libraries to digital services. During the pandemic, libraries must seize the chance to expand their services in order to survive and thrive and provide access to their resources. Due to the fact that each library's ability to adapt to this condition differs, not all libraries are able to provide ideal services during the COVID-19 pandemic, and so face a variety of obstacles in meeting their users' needs. Among the challenges confronting libraries during the COVID-19 outbreak are the following:

1. The library has a limited number of reference sources and resources;

2. Each library's financial capacity differs;

3. The library has a limited amount of material or technology;

4. Not all libraries have digital collections;

5. Inadequate librarian competence;

6. Ignorance among remote-access library users.

Together with these obstacles, libraries are expected to innovate and transform in service to users. There are several things that libraries can do during a pandemic, including: 
1. Promoting Libraries Using Online Media

Currently, there are a large number of users who require access to information but do not want to offend government recommendations to restrict activities outside the home; therefore, libraries provide an alternative to provide information online, allowing users to obtain information without disobeying government health protocols. On the positive side, online and social media platforms can be utilized to promote library services. Libraries can utilize social media to convey a variety of types of information, including information about library services, COVID-19 information, and information literacy programs. The promotion objective encompasses not only the academic community within the school, but also the broader community.

\section{The Developing Digital Library}

Until now, many libraries have evolved into hybrid libraries, which maintain physical access to services. When such circumstances exist, it provides a chance for libraries to create and develop digital libraries. If the library currently has a digital library, it can enhance and expand its capabilities in terms of quality, operation, display, and content, such as by providing information sources in digital form or e-resources to make it easier for users to access the information anywhere and at any time.

\section{Resource sharing or collaboration with other libraries}

Libraries that continue to have difficulties as a result of this epidemic might collaborate with other libraries to ensure that their services keep operating and that users have access to information as needed. Collaboration with other libraries can be in the form of exchanging physical and digital collections, sharing information, crossservice, and other activities. Libraries can take advantage of the collaboration network between libraries in each region. The objective of this project is to demonstrate how libraries can collaborate and supplement each other's lack of knowledge and resources in order to meet users' demands.

\section{Utilizing the free internet reference sources}

Libraries can use freely accessible online reference materials without purchasing or subscribing. The government supports the use of free digital reference sources such as IOS (Indonesia One Search), e-resources.pnri.go.id, sinta.ristekbrin.go.id, and garudadikti.go.id, as well as e-books and e-books. Apart from that, online reference sources can be accessed through smartphone applications such as IJogja, Ijakarta, and Ipusnas, as well as other online reference applications. 


\section{Delivery Services}

Restrictions on activities outside home recommended by the government prevent users from accessing the library's physical collections. Therefore the library provides a digital alternative usage of collections. If collection which is needed by the users is not available in digital format, the library can help distribute it. Delivery service might be physical or digital. The library makes it easier for users to obtain physical collections without having to physically visit the library by delivering them by courier or online motorbike taxi application. Meanwhile, digital information can be sent using onlinebased communication technology media.

The Innovative Role of Librarians

During the current pandemic, the librarian's active participation in adapting to new habits can be implemented in a variety of methods, including:

1. Provide collections/sources of information that can be accessed remotely (digital information)

2. Provide online services instead of face-to-face services.

3. Providing convenience in service without complicating the user

4. Provide free access to alternate sources of scientific reference (e-resources) (free access)

5. Creating service innovations that aim to provide information literacy education to users that can be accessed online, such as making video tutorials on library utilization, optimizing the use of e-resources, and optimizing the delivery of information services.

Integrated Library service app

In addition to these digital-based innovation services, it is expected that a government policy will be developed in the future to create an integrated application system that includes connections between libraries throughout Indonesia, with said possibility of having an international network managed by Indonesian domestic institutions. This service includes not only the campus library network, but also government and private-sector libraries.

The system used in digital platforms that are commonly used in e-commerce services can be adapted in this networked e-library service. With the increasing development of education and increasing demands for access to information and literature makes this form of e-service quite likely to be established by the government. 
Volume 4 Number 4 June 2021

\section{CONCLUSION}

The Covid-19 pandemic has had a significant impact on teaching and learning activities, particularly in libraries, which are one of the most important supports of good education. The Covid-19 outbreak has impacted the availability of instructional resources, reading materials, literacy, and other information.

Libraries must always innovate services by utilizing advances in information technology, such as developing e-digital library services, online libraries, books delivery services, and building big data and digital library applications that involve libraries throughout Indonesia. even the entire world can utilize the system used in digital platforms that are commonly used in e-commerce services can be adapted in this networked e-library service.

\section{ACKNOWLEDGEMENT}

1. Praise be to Allah SWT

2. Thank to Dr. Budi Rianto, MSi as Lecturer for Innovation Strategy Course

3. The classmates in MAP UHT 2020

\section{Author Contribution}

The personal writer has spent considerable time reading journals, literature, and novels in order to compile writing material.

\section{REFERENCES}

AD, Suharti (2020) Layanan Perpustakaan Di Masa Pandemi Covid 19, Bulletin Perpustakaan UII,3(2) 2020, 53-64.

Hapsari, Rian Dwi , Kuncoro G Pambayun, and Heri Iman Santoso, (2020), Library Services from Home ( Lsfh ): A Library Policy to Fight Covid-19 in Governance Institute of HomeAffairs," Indonesian Journal Of Librarianship 1, no. 1 (2020): $1-15$.

Huck, Azzi K., \&Shims, T. (2020), Managing the impact of COVID-19 on education systems around the world: How Countries are preparing, coping, and planning for recovery. World Bank. https://blogs.worldbank.org/education/

Sholeh, Mohamad (2008), Analisis Strategi Inovasi Dan Dampaknyaterhadap Kinerja Perusahaan (Studi Kasus : UKM Manufaktur di Kota Semarang), Tesis, Program Studi Magister Manajemen Program Pasca Sarjana Universitas Diponegoro, Semarang. 
Suharso, Putut Imaniar Putri Arifiyana, and Dewi Wasdiana, (2020), Layanan Perpustakaan Perguruan Tinggi Dalam Menghadapi Abstrak 4, no. 2 (2020): 271-86 